\title{
Life Cycle Sasmita in Raden Sulam Text as Javanese Ancestral Heritage
}

\author{
Gilda Azalia N.R. ${ }^{1}$, Turita Indah Setyani ${ }^{2}$, Novika Stri Wrihatni ${ }^{3}$ \\ 1,2,3 Javanese Study Program, Faculty of Humanities, Universitas Indonesia \\ dhani2896@gmail.com, turita.indah@ui.ac.id, novika.stri@ui.ac.id
}

\begin{abstract}
Raden Sulam $(R S)$ text is a text that tells about the journey of the main character named Raden Purbaningrat to study the science of religion. The story is framed with romance and war stories. $R S$ text is one of the classical Javanese literature works that contains many elements of Javanese religion, one of them is sasmita. This study discusses the link between sasmita and life cycle in Javanese culture that contained in $R S$ text. The purpose of this study is to outline the link between sasmita and the life cycle in the $R S$ text. The method used in this study is hermeneutics using the antroporeligio literary perspective. The hermeneutics method is used to describe as well as analyze the results obtained from the analysis as it is. The result of this research is the life cycle of sasmita that describes the phases of the birth of human inner consciousness until the separation of the soul and its attachment. These phases are used by Javanese people to understand various things that are around them not as an individual, but as unity. This study is one of cultural heritage and also can be a reference in future research for personal and others.
\end{abstract}

Keywords: Javanese classical text, Sasmita, Life cycle, Sign

\section{INTRODUCTION}

$R S$ text is one of the 17 th-century classical literary works dominated by religious concepts, such as sasmita. Etymologically, sasmita means 'sign' or 'symbol' [1]. According to Sumodiningrat \& Wulandari, sasmita can also be defined as a form of information that is symbolic [2]. Previous research that discusses sasmita is a journal article written by Dwi Bambang Putut Setyadi in 2010 with the title "Tembang Macapat Discourse as the Revealing Cognition System and Local Ethnic Wisdom of Java." The article discusses the sasmita contained in three tembang macapat, which are Tripama, Wulangreh, and Kalatidha. This study is a linguistic and literary study using discourse analysis method. The results of the study are three main points. First, structure and characteristics of discourse Tripama, Wulangreh, and Kalatidha. Second, sasmita that appears is in form of two things 1) a request to children and grandchildren to have good behavior and to abandon bad behavior; 2) maintaining the relationship between human beings with other people, environment, and God in daily life of Javanese ethnic. Third, macapat discourse reveals the ethnic cognition system of Java and local wisdom of ethnic Javanese [3].

The $R S$ text is a classical Javanese literary work written in macapat (classic Javanese poetry) form. The RS text is composed of 22 pupuh (corresponding to chapter in prose works). In generals pupuh-pupuh that written using a specific metrum (rules that related to the 
composition of the verse). Metrum that contained in the $R S$ text is the form of sasmita. Sasmita can be used to describe the life cycle of the main character named Raden Jaka Sulam in RS text (in the text, he is more commonly referred to as Purbaningrat).

Previous research about life cycle is a journal article written by Sudhir Kakar in 1968 with title "The Human Life Cycle: The Traditional Hindu View and The Psychology of Erik Erikson." This study is a psychology study using comparison method. In this journal, he states that life cycle is a link in the chain of generations. There are two points result in this research regarding the human life cycle. First, the Hindu view life cycle as something religious while Erikson's is clinical and developmental. Second, the Hindu theory is about combination of traits from previous life considering the psycho-social development of individual and ignores Erikson's first three stages [4].

As for the life cycle contained in $R S$ text is a series event of Purbaningrat's inner consciousness journey start from the birth of his inner consciousness until the separation of soul and its attachment.

\section{METHOD}

The method used in this assessment is hermeneutics. Hermeneutics is a method used to study literature that has connection with religion. In the literature field, hermeneutics can be aligned with interpretation, because initially, hermeneutics used to interpret the scriptures [5]. The analysis of this study used the antroporeligio (religious-anthropology) approaches. Those approaches are considered suitable for this study because this study discusses sasmita and life cycle in Javanese society through the perspective of anthropology and religion. The work steps are undertaken in this research consist of several stages. First, filter the data in the form of pada. Second, analyze each data. Third, interpret data based on religious and anthropology perspectives.

\section{RESULT AND DISCUSSION}

Macapat in Javanese culture also has a philosophical meaning related to human life cycle start from birth to death. According to Supadjar [6] the order of metrum macapat that describes the life cycle are mijil, sinom, durma, asmaradana, kinanthi, gambuh, pangkur, pocung. The depiction of life cycle in each metrum is represented by major events in life, along with its depiction. Mijil in the life cycle is a representation of birth phase. Sinom in macapat connotes in youth period. Durma also portrays the youth period, but the youth described is link to those things that are unstable and susceptible to all bad things, such as irritability, quarreling, and contentment. Asmaradana illustrates the time when humans are in a phase of falling in love. Kinanthi connotes in marriage which is a phase of union between two different people that filled with compassion and love. Dhandhanggula is a picture of wise acts, because it feels old and experienced. Gambuh in the life cycle describes the mature age that can meet and adjust the needs of the inner and body, the community, and God. Pangkur connotes in the elderly and the time where human has put aside worldly things. Pocung or pucung describes the time of death, when humans reach this period the human relationship with the world has been cut off.

The order of the metrum macapat based on Supadjar's opinion becomes a reference to the life cycle picture in Javanese society. The analysis of life cycle that contained in $R S$ text is done by looking at the metrum and comparing it sequences in the $R S$ text with a general sequence based on Supadjar's opinion. As for, the order of life cycle contained in the $R S$ text consists of, 
asmaradana, pangkur, sinom, dhandhanggula, mijil, pucung, durma, kinanthi, gambuh, and megtruh. The detail of life cycle analysis in RS text can be seen in the comparison table below.

Table 1 Comparing Life Cycle in Supadjar and The RS Text

\begin{tabular}{|c|c|c|c|}
\hline \multicolumn{2}{|r|}{ Supadjar } & \multicolumn{2}{|c|}{ The $R S$ Text } \\
\hline Tembang & The Life Cycle & Tembang & The Life Cycle \\
\hline Mijil & The birth phase & Asmaradana & $\begin{array}{l}\text { The born of inner } \\
\text { consciousness phase }\end{array}$ \\
\hline Sinom & The youth period & Pangkur & $\begin{array}{l}\text { The phase of reduce } \\
\text { everything that is worldly }\end{array}$ \\
\hline Durma & $\begin{array}{l}\text { The youth period described } \\
\text { link to those things that are } \\
\text { unstable and susceptible to } \\
\text { all bad things }\end{array}$ & Sinom & $\begin{array}{l}\text { The phase of inner } \\
\text { deepening }\end{array}$ \\
\hline Asmaradana & A phase of falling in love & Dhandhanggula & $\begin{array}{l}\text { The phase of unification of } \\
\text { love }\end{array}$ \\
\hline Kinanthi & The marriage phase & Mijil & $\begin{array}{l}\text { The phase of beginning to } \\
\text { performing the task }\end{array}$ \\
\hline Dhandhanggula & A phase of wise acts & Pucung & $\begin{array}{l}\text { The phase of inner } \\
\text { liberation of worldly things }\end{array}$ \\
\hline Gambuh & The mature age phase & Durma & An inner conflict phase \\
\hline Pangkur & $\begin{array}{l}\text { The elderly phase and the } \\
\text { time where human has put } \\
\text { aside worldly things }\end{array}$ & Kinanthi & Manunggaling kawula Gusti \\
\hline Pocung & The time of death & $\begin{array}{l}\text { Gambuh } \\
\text { Megtruh }\end{array}$ & $\begin{array}{l}\text { Manunggaling Gusti kawula } \\
\text { The phase of separation of } \\
\text { soul and attachment }\end{array}$ \\
\hline
\end{tabular}

\subsection{The inner consciousness phase}

Koentjaraningrat in one of his article called Javanese Term of God and Supernatural Beings and The Idea of Power, state that Yasadipura I (the court poem), in his text with title serat cabolek propose that Javanese people to let their inner spiritual life to the values and ideals of Javanese culture, which is the search for spiritual purification and perfection as well as the attainment in the divine unity [7].

The definition of consciousness its self can be denoted as sensation, perception, memory, imagination, thought, emotion, desire, will [8]. It can be said that consciousness is something that wide and religiously can also be interpret as inner emotion. Hence, the inner consciousness can synchronize as the inner spiritual

As the Koentjaraningrat's said above, it is a proof that Javanese people in its culture are encouraged to have desire in searching for each inner consciousness, which means the born of inner consciousness. In RS text we can see that from story part that describe this phase as below.

Metrum asmaradana in $R S$ text tells abaout Purbaningrat demanded by his father, King Prabu Purbakusuma to marry and ascend the throne to become King in Bandaradzim. However, Purbaningrat felt that he had not been able to be a great king for his country, so he asked his father for permission to go to Yalkah, because he wanted to study science of religion. Prabu Purbakusuma who heard his son's wish, gave his son permission [9]. Major events on metrum asmaradana is in form of Purbaningrat who asked permission to his father to study sceince of religion in Yalkah. That major events become sasmita, that based on religious perspective can be interpreted as a form of birth of inner consciousness in human heart. Purbaningrat's desire to study has shown that he has been conscious of his inner needs. Therefore, the major event in 
metrum asmaradana based on the context of the life cycle can be interpreted as a the born of inner consciousness phase.

\subsection{The phase of beginning to reduce everything that is worldly}

This metrum in $R S$ text tells about Purbaningrat and Sekapraya who do tapa (meditate) on the mountain for guidance. At the time of their tapa, Umar Maya suddenly descends from the sky and gives them a clue [9]. Major events in story section from $R S$ text is Purbaningrat and Sekapraya do tapa on the edge of the mountain. Based on religious perspective tapa is also considered as a form of praying activity. At the time of prayer, everything related to the world is set aside, because the important thing is to achieve the goal of the act of prayer or tapa. So, the life cycle that described in this metrum is the phase of beginning to reduce everything that is worldly.

\subsection{The phase of inner deepening}

This metrum in $R S$ text tells about Purbaningrat meeting Purbaningsih to ask for his kris back. Purbaningsih agreed to return the keris, but on condition that Purbaningrat sould teach her the shahada. Purbaningsih asked Purbaningrat to teach her, because she wanted to convert to Islam. Purbaningrat who heard the princess request was very happy, then Purbaningrat and Purbaningsih sat in line, then the princess had said the shahada and has converted to Islam. Purbaningsih felt very happy, as a thank you she returned Purbaningrat's kris. The kris had been received by Purbaningrat and tucked back to his waist [9].

The major event contained in the story from $R S$ text is Purbaningsih who asked Purbaningrat to help her convert to Islam. Purbaningsih's action that asked Purbaningrat's help was a form of effort to deepen the inner dept. Hence, the life-cycle phase contained in the story is inner deepening.

\subsection{The phase of unification of love}

Metrum dhandhanggula in RS text narrated that after entering Islam Purbaningsih and Purbaningrat do a mutual gentle persuasion. The two of them flatter each other with sweet words [9]. The major event contained in the metrum dhandhanggula is in the form of gentle persuasion between Purbaningrat and Purbaningsih who are in love. The act of persuasion contained in that major event is sasmita that shows the effort to unite the feelings of two people who are in love. The unification in this analysis is the unification of love between two people who have not been legally bound and adrift to happiness. In the life cycle that major event is the initial phase of the unification of love.

\subsection{The phase of task fulfillment}

Metrum mijil in $R S$ text tells about Purbaningrat who told Minawati (the wife) that he wanted to go back to the mainland, because he wanted to take revenge on King Johan Pirman. Minawati who heard Purbaningrat's wishes felt very sad, because she will be separated from her husband. Purbaningrat also persuaded Minawati not to be sad anymore [9]. The major event contained in the story from $R S$ text is about Purbaningrat who asked permission from his wife, Minawati to go take revenge on King Johan Pirman. Referring to the life cycle, that event become sasmita that can be interpreted as an act of Purbaningrat task fulfillment. In the Javanese 
religious perspective, the revenge contained in that major event is Purbaningrat's way of doing his job in the world, which is, by crushing evil. Starting from birth every human has been determined their duty and fate in the world. According to Suseno [10] if man fulfills his duty in the world, then the world order will be preserved. Thus, the Phase contained in the quotation is task Fulfillment.

\subsection{The phase of inner liberation of worldly things}

Metrum pucung in $R S$ text tells about Purbaningrat, Sekapraya and Darudana talah up in Kebar State. They saw that many soldiers guarding the place where King Johar Manik was arrested. Purbaningrat immediately release aji sirep (spell to put people to sleep). All the soldiers who guard were asleep, none of them woke up. The three men immediately went to the place where King Johar Manik was arrested, then Purbaningrat recited a spell and the prison door opened on his own. King Johar Manik was immediately taken out by Darudana [9]. Metrum pucung in the $R S$ text contain a major event about Purbaningrat and Sekapraya helping Darudana in releasing King Johan Pirman who was detained by King Kebar. That event is sasmita that can be interpreted as an attempt to free inner mind from the bondage that holds it which is lust. The major event of that quotation is a metaphor in the effort to liberate the mind from the restraining shackles in order to be closer to the god. Therefore, the life cycle phase of metrum pucung is the inner liberation of worldly things.

\subsection{An inner conflict phase}

In $R S$ text, metrum durma contains about war between the Johar Manik and Kebar. In the battle between Johar Manik and Kebar, many soldiers from Johar Manik died, because overwhelmed in the battlefield. Sekapraya who saw that felt unbearable and wanted to go to help the soldiers of Johar Manik in the battlefield. Sekapraya asked permission from Purbaningrat to go to war and he got the permission. He immediately went by riding his horse to the battlefield and brought a long sword. Sekapraya hit the enemy with his lightning-like pace, then he began to move to the center, he was full of self-confidence, Sekapraya raging to the army of Kebar. There were a lot of Kebar warrior who died in the battlefield. Darudana who saw the battlefield situation also wanted to help, then he asked permission to Purbaningrat and allowed. Darudana immediately rode his horse while holding the sword, then he hit a lot of warriors Kebar [9].

Major events contained in that story section from $R S$ text tells about the fight between Johar Manik and Kebar. The battle illustrates the conflicts that occur between some groups that usually represent the two main traits in the world, which is good and evil. In the context of Javanese religion, the conflicts of the two main traits in the world can be synchronized with the inner conflicts found in human heart. In general, every human being has good and bad qualities in them self and only them self can decide which character will be more highlighted. Based on the analysis, the life-cycle phase that contained in metrum durma is an inner conflict phase.

\subsection{Manunggaling kawula Gusti}

Based on Paguyuban Sumarah teach, Manunggaling Kawula Gusti is the culmination of achieving unity between the human consciousness and the substance of God [11]. Metrum kinanthi in $R S$ text tells about Purbaningrat, Sekapraya and Darudana who have married their spouses. Purbaningrat married to Darusasi, Sekapraya married Gendharawati, and Darudana 
married Gendrasari [9]. The major events from the story in metrum kinanthi is about Purbaningrat, Sekapraya, and Darudana marriages with their spouses. Religiously the marriage in the story is the sasmita that interpreted as the unite of human consciousness with the substance of God. This is based on Javanese people perspective about mariage. Herusatoto [12], states that spiritually marriage is a form of the unity of human consciousness (cipta) and body (raga), means his/her consciousness and body are no longer connect with worldly matter and have reach the highest phase in inner consciousness life cylce, namely Manunggaling Kawula Gusti.

\subsection{Manunggaling Gusti kawula}

Metrum gambuh in $R S$ text tells about Darudana who has ascended the throne to become King in Johar Manik with title Jayawiguna. Jayawiguna has been faced by the great warriors, then Purbaningrat has arrived and was invited to sit in a row with Jayawiguna. After that, Darudana who had ascended the throne to become the King of Kebar with the title Jayasengara had arrived, then he was invited to sit in rows with the king. All had sat neatly and saluted the king [9].

Major events contained in that story is the sitting position of Purbaningrat, Jayawiguna, and Jayasengara. This major event is sasmita that from the perspective of religion that in life there is no high level of low level, there is only a relationship between human and God. It is described from the sitting position of Purbaningrat, Jayawiguna, and Jayasengara that are parallel. In the life cycle after man reach maturity, he is not concerned with his position in the world, because he has conciousness be one with God (manunggaling Gusti kawula). Hence, the phase that conataned in the story is the human relationship with God.

\subsection{The phase of separation of soul and attachment}

In the metrum megatruh described that Purbaningrat has entered into the palace. Purbaningsih who accompanied by an emban (nanny) picks Purbaningrat. After that, Purbaningrat expressed his desire to go to the study science of religion. Purbaningsih who heard Purbaningrat wishes felt very sad because she will be separated from her husband [9].

The great event contained in the megatruh metrum was Purbaningrat who expressed his wish to Purbaningsih to go to the study science of religion. Purbaningrat's act of wishing to go to study science of religion is sasmita in the life cycle described the separation of body and soul. Based on the ancestor teachings couple who are married means the consciousness (cipta) and body (raga) have been unite [12]. When the couple parted, then the consciousness and body also separate. This kind of separation does not denote as death, but means that the separation of consciousness and everything that attach to it. After the separation, instead of belong to the personal, the consciousness belongs to the universe. Thereafter the phase contines in this metrum is the separation of consciousness and the attachment [13].

\section{CONCLUSION}

Based on the decomposition, it can be concluded life cycle of sasmita in RS text that interpreted from major event as the cycle of inner consciousness start from the born until the separation with the attachment. This kind of cycle is always use in Javanese people life as a role model used to interpret the phase on the life cycle until can be Manunggaling Kawula Gusti. 


\section{REFERENCES}

[1] Utomo, Sutrisno Sastro, Kamus Lengkap: Jawa-Indonesi”a, Kanisius, 2009, p.166

[2] Sumodiningrat, Gunawan dan Ari Wulandari, "Pitutur Luhur Budaya Jawa", Narasi, 2014, p.397

[3] Setyadi, D.B Putut, "Wacana Tembang Macapat Sebagai Pengungkap Sistem Kognisi dan Kearifan Lokal Etnik Jawa”, Kajian Linguistik dan Sastra, Vol. 22, No. 2, 2010.

[4] Kakar, Sudhir, "The Human Life Cycle: The Traditional Hindu View and The Psychology of Erik Erikson", Philosophy East and West, University of Hawaii Press, "Vol 18, No. 3, Jul 1968

[5] Ratna, Nyoman Kuta, "Teori, Metode dan Teknik Penelitan Sastra", Pustaka Pelajar, 2015, p.45

[6] Supadjar, Damardjati, "Etika dan Tatakrama Jawa Dahulu dan Masa Kini”, Keadaan dan Perkembangan Bahasa, Sastra, Etika, Tatakrama, dan Seni Pertunjukan Jawa, Bali dan Sunda, Javanologi Direktorat Kebudayaan Departemen P dan K, 1985, p.194

[7] Koentjaraningrat, "Javanese Term for God and Supernatural Being and The Idea of Power”, Man, Meaning and History, Brill, 1980, p.131.

[8] Scott, William Henry, "Consciousness and Self-Consciousness", The Philosophical, Duke University Press, Vol 27, No.1, Jan 1918, p. 2.

[9] Zenny, Rahmawati, "Naskah Raden Sulam: Suntingan Teks", Fakultas Ilmu Pengetahuan Budaya, 2014.

[10] Suseno-Franz Magnis, Etika Jawa, Gramedia, 1984.

[11] Saputra, Fendi Gatot, "Penghayatan Ketuhanan", Jurnal Filsafat, Universitas Gajah Mada, Vol 19, No. 2, 2009, p.134-135.

[12] Herusatoto, Budiono, "Konsepsi Spiritual Luhur Jawa”, Ombak, 2009, p.71-72.

[13] K. Saddhono and S. Supeni. "The role of dutch colonialism in the political life of Mataram dynasty: A case study of the manuscript of Babad Tanah Jawi." Asian Soc. Sci. vol. 10 no. 15 pp. $1-7,2014$ 